\title{
THE AESTHETICS OF ARCHITECTURE
}





\section{THE AESTHETICS OF ARCHITECTURE \\ ROGER SCRUTON}

WITH A NEW INTRODUCTION BY THE AUTHOR 
Introduction to the 2013 Edition (C) 2013 by Princeton University Press

Published by Princeton University Press, 41 William Street, Princeton, New Jersey 08540

In the United Kingdom: Princeton University Press, 6 Oxford Street, Woodstock, Oxfordshire OX20 1TW

$$
\text { press.princeton.edu }
$$

Jacket Photo: Radcliffe Camera, Oxford. Photographed from Exeter College Fellows' Garden on June 26, 2012 by Mark Vanstone. Images tonemapped in Luminance HDR and stitched using Hugin.

\section{All Rights Reserved}

First printing, 1979

Second printing, with corrections, 1980

Paperback reissue, with a new introduction by the author, 2013

Library of Congress Cataloging-in-Publication Data

$$
\text { Scruton, Roger. }
$$

The aesthetics of architecture / Roger Scruton.

pages $\mathrm{cm}$

"Paperback reissue, with a new introduction by the author."

Includes bibliographical references and index.

ISBN 978-0-691-15833-4 (pbk. : alk. paper) 1. ArchitectureAesthetics. I. Title.

NA2500.S43 2013

$$
\text { 720.1-dc23 } 2012040982
$$

This book has been composed in Sabon LT Std and Gill Sans

Printed on acid-free paper. $\infty$

Printed in the United States of America 
Die Menschheit hat ihre Würde verloren, aber die Kunst hat sie gerettet und aufbewahrt in bedeutenden Steinen.

(Mankind has lost its dignity, but Art has recovered it and conserved it in significant stones.) 
